\title{
EFFECT OF TACTILE STIMULATION ON NEONATAL STRESS DURING INVASIVE PROCEDURES AT NEONATAL INTENSIVE CARE UNITS OF PORT SAID
}

\author{
Amal Ahmed Khalil', Azza Mohammed Fathi², Amany Ali Abd El halim ${ }^{3}$ \\ Professor of Pediatric Nursing ${ }^{1}$, lecturer of Pediatric Nursing, \\ Faculty of Nursing, Port Said University ${ }^{2}$, B.Sc Nursing, Mansoura University ${ }^{3}$
}

\begin{abstract}
Background: Tactile stimulation has a great effect on decreasing neonatal stress during invasive procedures in neonatal intensive care units. Aim of the study: The study aimed to assess the effect of tactile stimulation on neonatal stress during invasive procedures at neonatal intensive care units. Design and setting: A quasi-experimental research design was used in this study, which was implemented in neonatal intensive care units Port Said, PortFouad and El-Nasr General Hospitals in Port Said. Sample: A sample of 130 neonates were used in the study. Tools: Data were collected by using three tools the first for neonatal characteristics, the second for assessment of neonatal blood sample (invasive procedure) and the third for stress physiological, behavioral \& motor measurements. Results: There were high statistically significant differences in physiological, behavioral \& motor measurements between two methods (with \& without tactile stimulation) and the degree of neonatal stress control during invasive procedures in NICUs. Moreover, there was high statistically significant differences between two methods (with \& without tactile stimulation) regarding total stress score and the degree of neonatal stress control during invasive procedures in NICUs, p value <0.001. Conclusion: The application of tactile stimulation has a positive effect on neonatal degree of stress among daily painful invasive procedures in NICUs. Recommendations: Continues implementing training program on tactile stimulation technique as a technical skill for nursing staff and implement further studies to investigate the effect of tactile stimulation on stress in different settings.
\end{abstract}

Keywords: intensive care units, invasive procedures, stress, neonates, tactile stimulation, 


\section{INTRODUCTION}

Newborns often experience numerous painful procedures in the course of their monitoring and treatment (Slater et al, 2012). These procedures average between 7.5 and 17.3 painful procedures daily, the most frequent being heel lance, suctioning, venipuncture and cannulation (Cruz et al, 2016). Repeated exposure to painful procedures, adversely affects the newborn's physiological, neurological status, including changes to brain microstructure and function, neurodevelopment, stress systems, and stress-sensitive behaviors (Grunau, 2013; Ranger et al, 2013).

Stress is not always harmful and might be necessary to maintain life; although, it can be deleterious to health involves the hypothalamus, pituitary, amygdala, gray matter and adrenal glands, stress makes interruption of Autonomic Nervous System (ANS) development, which associated with changes in blood pressure, tachycardia, poly apnea, increased oxygen consumption, hypoxemia, intraventricular hemorrhage and myocardial ischemia. This release of endorphins and cytokines can cause changes in skin color and noninfectious inflammatory syndrome (Slater et al, 2012).

Medical and technological developments over the last few decades have increased the survival rates of infants born as preterm. But their admission in NICUs provides them numerous stressors including painful stimuli, excessive noise and light, in addition disruption of sleep which affect the development of neonates in various ways and may have direct effects on brain development and learning that continue after the infant has been discharged home (Holditch-Davis, 2010) .

The use of non-pharmacologic therapies is often recommended as the first step in neonatal pain management, particularly because of their favorable side-effect profile, their ability to diminish acute pain from invasive or noninvasive procedures. In addition, their beneficial long-term effects as compared to the systemic analgesics the use rate for nonpharmacologic interventions was $18 \%$ compared with $2 \%$ for pharmacologic intervention (Johnston et al, 2011; Hall \& Anand, 2014). Non-pharmacological analgesic has positive 
outcomes, which range from typical brain development to improved cognitive functioning (Feldman et al, 2014).

The current Neonatal Intensive Care Units (NICUs) efforts for modifying the neonates' environment focuses on moderate pressure massage (Tactile stimulation) of physiologically stable premature neonates and firm/moderate pressure stroking (Kulkarni et al, 2010). Moreover, tactile stimulation as one of non-pharmacological therapies can reduce stress hormone levels, but even newborns have shown signs of distress when confronted by unresponsive, expressionless faces. At chemical level, affectionate touch and other nurturing behaviors appear to trigger the release of neurotransmitters, like oxytocin and endogenous opioids (Feldman et al, 2010).

The application of tactile stimulation has a positive effect on neonatal degree of stress among daily painful invasive procedures in NICUs. Therefore, the pediatric nurse learns and implements this technique in daily routine care in NICUs to overcome the impacts of neonatal stress.

\section{Significance of the study:}

Pain and stress experienced by the newborn have not been addressed adequately; neonates in NICUs often undergo painful and stressful invasive procedures, and inappropriate treatment that increases morbidity and mortality (Lemus-Varela et al, 2014). Neonates required carefully observation and assessment to decrease stress and relieve pain that they were exposed to daily in NICUs, studying the effect of tactile stimulation on stress has become more important. The results of this study could be important in clinical filed and bringing benefits to organization.

\section{AIM OF STUDY:}

The aim of this study was to assess the effect of tactile stimulation on neonatal stress during invasive procedures at neonatal intensive care units of Port Said. 


\section{SUBJECTS AND METHOD:}

\section{Research design:}

A quasi-experimental research design was followed in this study.

\section{Study setting:}

The study was conducted in El-Naser General Hospital, Port Said General Hospital and Port Fouad General hospital. These hospitals were affiliated to the Ministry of health.

\section{Study subjects:}

The subjects were involved in this study consisted of 130 of neonates affiliated to the above-mentioned settings by convenience sampling. To achieve the study objective, the sample size was determined by using time serial in ten months in the period between May14 2015 to March12 2016.

\section{Tools of data collection:}

\section{Three tools were used to collect data for this study}

\section{Tool I: Neonatal characteristics data sheet:}

Neonatal characteristics data sheet: Developed by researcher: It included questions about newborns data: as (name, gestational age, age when started the study, birth date, gender, weight when started the study, diagnosis, date of admission, date of discharge, method of feeding, method of delivery, method of oxygen therapy, analgesic treatment).

\section{Tool II: Blood sample assessment sheet (invasive procedure):}

It developed by (Moselhi, 2010): It measured two times the first with tactile stimulation and the second without tactile stimulation in two followed days on the same neonates. It includes eight question about characteristics of blood sampling of neonates as (date of sampling, time, site of insertion, duration of insertion, number of trails, local anesthesia, if there complication at site of insertion, type of complication at insertion site as thrombosis, hematoma and extravasation). 


\section{Tool III: Stress assessment scale:}

Stress assessment scale by (Modrcin -McCarthy et al, 1997) and modified by (Abd Elmotalib, 2008). Also modified by the researcher by adding sub categories of each items of physiological as base line of heart rate, respiration \& behavioral measurements as cry, sleep pattern classification depending on pain assessment scale of (Moselhi, 2010) to be suitable for the aim of the study. Then made jury consisting of five experts in the field of Pediatric Nursing, Port Said University and Cronbach Alpha Coefficient was used to assess the internal consistency tool and its value was 0.72 .

\section{It divided into two parts:}

\section{Part I: Autonomic and physiological measurements:}

Autonomic and physiological measurements include five items, four of them filled in monitor as respiratory rate, heart rate, oxygen saturation, blood pressure and one item measured by observation, which is skin color. All items measured before, during and after invasive procedure two times the first with tactile stimulation and the second without tactile stimulation.

\section{Part II: Motor and Behavioral measurements:}

Behavioral and motor measurements including five items: activity, overall tone, cry, facial expression and sleep. All stress indicators measured before, during and after invasive procedures.

\section{The scoring system:}

The response of neonates to stress ranges from (0-3) to each item in the scale:

(0) No stress occurred, (1) Mild stress occurred, (2) Moderate stress occurred, (3) Severe stress occurred.

-Physiological score ranged from (0-15): No stress when scores were (0), mild stress (1-5), moderate stress (6-10), severe stress (11-15). 
-Motor score ranged from (0-6): No stress when scores were (0), mild stress (1-2), moderate stress (3-4), severe stress (5-6).

-Behavioral score ranged from (0-9): No stress when scores were (0), mild stress (1-3), moderate stress (4-6), severe stress (7-9).

-Total stress measured by score: (0-10) adequate stress control. (>10) inadequate stress control.

These score converted into a percent score, and means and standard deviations were computed.

\section{-The content validity of tool:}

It was ascertained by a jury consisting of five experts in the field of Pediatric Nursing, Port Said University. Necessary modification were done according to experts' opinion and its value was $80 \%$.

\section{2-Reliability of tool:}

It was held on 13 neonates in NICUs. Cronbach Alpha Coefficient was used to assess the internal consistency tool and its value was 0.72 .

\section{PilotStudy:}

The study was carried out on $10 \%$ (13 neonates) to test applicability of the tool then necessary modification was done according to the result of pilot study, and to estimate the time needed for collecting data (these $10 \%$ of neonates will excluded from the sample size $=130$ neonates).

\section{Field Work:}

Data was collected from the selecting settings the most number was 86 neonates from El-Naser General Hospital, 28 neonates from Port Fouad General hospital and16 neonates from Port Said General Hospital, using the pre-constructed tools the data collected lasted for ten months in the period between May 14th 2015 until March 12th 2016. The researcher 
went to neonatal intensive care units two followed days in the week in the morning shift from 9 am: $12 \mathrm{pm}$ on the same group of neonates.

The researcher filled neonatal characteristics sheet from nursing and medical records. The blood-sampling sheet filled by observation to staff nurse when they had taken blood sampling and stress tool divided into two parts: the first autonomic and physiological measurements include five items; four of them filled in ECG monitor as: respiratory rate, heart rate, oxygen saturation, blood pressure and one item measured by observation, which is skin color. In addition, the second behavioral and motor measurement by observation.

The researcher measured stress without tactile stimulation to group of neonates by using the pre constructed tools, for (1min) repeated 3times before, during and after t invasive procedure (blood sample) to assess neonatal stress until return to base line .Then in the following day the researcher implemented tactile stimulation procedure before starting blood sample for $(15 \mathrm{~min})$ divided into three stages two five-minute phases of tactile stimulation and one five-minute phase of kinesthetic stimulation given during the middle phase. Then measured stress for (1min) repeated 3times, before, during and after invasive procedure (blood sample) until return to base line. Finally made a comparison between the two methods to determine the effect of tactile stimulation on neonatal stress.

\section{The procedure of Tactile Stimulation:}

The massage sessions comprised three segments, which were two five-minute phases of tactile stimulation and one five-minute phase of kinesthetic stimulation given during the middle phase.

During tactile stimulation, in first phase ,the neonate was placed in prone position and stroked with the fingers of both hands of the researcher for 5 minute periods over each region in the following sequence: 1) from the top of the head to the neck, 2) from the neck across the shoulders and back to the neck, 3) from the upper back to the buttocks and revere to the upper back, 4) from the thigh to the foot to the thigh on both legs simultaneously, and 5) from the shoulder to the hand to the shoulder on both arms simultaneously. For the kinesthetic second phase, neonate was placed in supine position. This phase consisted of six 
passive flexion/extension movements, each lasting approximately 10 seconds. These movements occurred in the following sequence: 1) right arm, 2) left arm, 3) right leg, 4) left leg, and 5) both legs simultaneously. Finally, tactile stimulation was repeated for 5minutes in third phase (Aliabadi \& Askary, 2013).

\section{(III) ADMINISTRATIVE DESIGN:}

Before conduction of the study, an official letter was taken from the dean of the Faculty of Nursing in Port Said University to the directors of hospitals at Port Said general hospital, El-Nasr hospital and Port Fouad hospital to obtain their approval. After an explanation of the purpose of the study, a written permission was secured from them.

\section{(IV) Ethical Consideration:}

-On data collection, a verbal agreement was taken from every neonate's parent after a clear and simple explanation of the purpose of the study, and that the information will be used for scientific research only and will be treated as confidential.

-A brief explanation of the study was given assured to the head nurses of NICU and staff nurses who made invasive procedure to gain their cooperation.

\section{(v)STATISTICAL DESIGN:}

Data entry and statistical analysis were done using SPSS 16.0 statistical software package. Data were presented using descriptive statistics in the form of frequencies and percentages for qualitative variables, and means and standard deviations for quantitative variables. Quantitative continuous data were compared using Student t-test in case of comparisons between two groups. Qualitative categorical variables were compared using chi-square test. Statistical significance was considered at $\mathrm{P}$-value $<0.05$ and $\mathrm{p}<0.001$.

\section{RESULTS:}

Table (1): illustrates the neonatal characteristics . It is clear from the table that more than half of neonates (55.3\%) aged 10-14 days and (40.7\%) were diagnosed as respiratory distress. 
Table (2): represents assessment of neonates in blood sample. It is shown from the table that the majority of neonates $(85.3 \%)$ were exposed to repeated third trail of needle insertion, and the majority of them (80.7\%) had the insertion duration lasted from 5-10 minutes.

Table (3): regarding total stress score, it illustrates that there were statistically significant differences between total stress score and tactile stimulation. During invasive procedures $p$ value $<0.001$ during invasive procedure, only $0.8 \%$ of neonates without tactile stimulation compared to $2.3 \%$ of them with tactile stimulation were normal,16.9\% of neonates without tactile stimulation compared to more than three quarters $(77.7 \%)$ of neonates with tactile stimulation had mild stress. Nevertheless, the majority of neonates (78.5\%) without tactile stimulation compared to $20 \%$ of them with tactile stimulation had moderate stress, $3.8 \%$ without tactile stimulation compared no one of neonates with tactile stimulation had severe stress.

Table (4): presents that there were high statistically significant differences between two methods (with \& without tactile stimulation) and stress control $\mathrm{p}$ value $<0.001$ in total stress score. It is clear from the table that $17.6 \%$ of neonates without tactile compared to the majority of them (80\%) with tactile stimulation had adequate stress control. On the other hand, the majority of neonates $(82 \%)$

without tactile compared to $20 \%$ of them with tactile stimulation had inadequate stress control. 
Table (1): Neonatal characteristics in percentage distribution $(n=130)$ :

\begin{tabular}{|c|c|c|c|}
\hline & NO & $\%$ & Mean \pm SD \\
\hline $\begin{array}{l}\text { Age when study started in days: } \\
1-5 \\
5-10 \\
10-14\end{array}$ & $\begin{array}{l}40 \\
18 \\
72\end{array}$ & $\begin{array}{l}30 \\
13.8 \\
55.3\end{array}$ & $4.7000 \pm 3.16387$ \\
\hline $\begin{array}{l}\text { Gestational age in weeks: } \\
35-36 \\
37-39 \\
>40\end{array}$ & $\begin{array}{l}9 \\
120 \\
1\end{array}$ & $\begin{array}{l}6.9 \\
92.3 \\
0.8\end{array}$ & $37.54 \pm 5.48$ \\
\hline $\begin{array}{l}\text { Weight when study started in grams: } \\
1500-2500 \\
2750-3750 \\
>4000\end{array}$ & $\begin{array}{l}39 \\
89 \\
2\end{array}$ & $\begin{array}{l}30 \\
68.4 \\
1.5\end{array}$ & $2.81 \pm 0.68$ \\
\hline $\begin{array}{l}\text { Gender: } \\
\text { Male } \\
\text { Female }\end{array}$ & $\begin{array}{l}81 \\
49\end{array}$ & $\begin{array}{l}62.3 \\
37.7\end{array}$ & \\
\hline $\begin{array}{l}\text { Method of delivery: } \\
\text { Normal } \\
\text { Caesarian section }\end{array}$ & $\begin{array}{l}25 \\
105\end{array}$ & $\begin{array}{l}19.2 \\
80.8\end{array}$ & \\
\hline $\begin{array}{l}\text { Diagnosis: } \\
\text { Respiratory distress syndrome } \\
\text { Transient tachypnea of neonate } \\
\text { Preterm } \\
\text { Neonatal jaundice } \\
\text { Sepsis } \\
\text { Infant of diabetic mother } \\
\text { Meconium aspiration }\end{array}$ & $\begin{array}{l}53 \\
23 \\
9 \\
37 \\
6 \\
1 \\
1\end{array}$ & \begin{tabular}{l|}
40.7 \\
17.6 \\
6.9 \\
28.4 \\
4.6 \\
0.8 \\
0.8
\end{tabular} & \\
\hline
\end{tabular}


Table (2): Percent distribution of data regarding invasive procedure (blood sample) technique $(\mathrm{n}=130)$ :

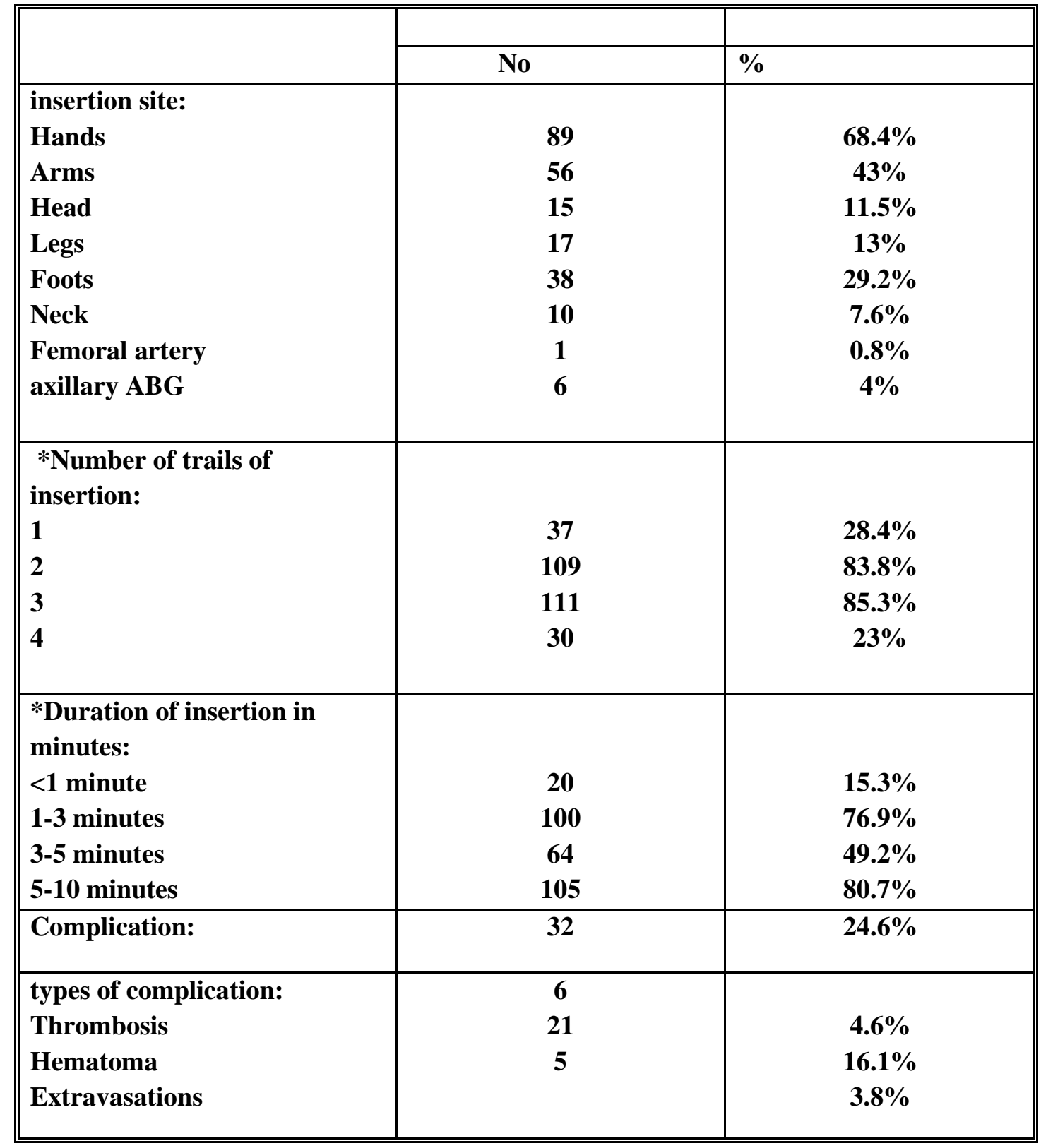

*Not mutually exclusive 
Table (3): Comparison between two methods (without and with tactile stimulation) regarding total stress score before, during and after invasive procedure in percentage

\begin{tabular}{|c|c|c|c|c|c|c|c|c|c|c|c|c|}
\hline \multirow{3}{*}{$\begin{array}{l}\text { Degree of } \\
\text { stress }\end{array}$} & \multicolumn{4}{|c|}{ Before } & \multicolumn{4}{|c|}{ During } & \multicolumn{4}{|c|}{ After } \\
\hline & \multicolumn{2}{|c|}{$\begin{array}{l}\text { With tactile } \\
\text { stimulation }\end{array}$} & \multicolumn{2}{|c|}{$\begin{array}{c}\text { Without } \\
\text { tactile } \\
\text { stimulation }\end{array}$} & \multicolumn{2}{|c|}{$\begin{array}{l}\text { With tactile } \\
\text { stimulation }\end{array}$} & \multicolumn{2}{|c|}{$\begin{array}{c}\text { Without } \\
\text { tactile } \\
\text { stimulation }\end{array}$} & \multicolumn{2}{|c|}{$\begin{array}{c}\text { With } \\
\text { tactile } \\
\text { stimulatio } \\
\text { n }\end{array}$} & \multicolumn{2}{|c|}{$\begin{array}{l}\text { Without tactile } \\
\text { stimulation }\end{array}$} \\
\hline & NO & $\%$ & No & $\%$ & No & $\%$ & No & $\%$ & No & $\%$ & No & $\%$ \\
\hline Base line & 101 & 77.7 & 83 & 63.8 & 3 & 2.3 & 1 & 0.8 & 98 & 77.4 & 36 & 27.7 \\
\hline Mild & 27 & 20.8 & 46 & 35.4 & 101 & 77.7 & 22 & 16.9 & 30 & 23 & 93 & 71.5 \\
\hline Moderate & 2 & 1.5 & 1 & 0.8 & 26 & 20 & 102 & 78.5 & 2 & 1.5 & 1 & 0.8 \\
\hline Severe & & & & & $\mathbf{0}$ & $\mathbf{0}$ & 5 & 3.8 & & & & \\
\hline Mean \pm SD & 6.84 & $=2.58$ & 6.3 & 2.68 & 17.7 & \pm 2.57 & 13.6 & 2.33 & 5.91 & $=2.35$ & & 2.38 \\
\hline$\chi^{2}$ & \multicolumn{4}{|c|}{7.039} & \multicolumn{4}{|c|}{101.865} & \multicolumn{4}{|c|}{59.195} \\
\hline $\mathbf{P}$ & \multicolumn{4}{|c|}{$0.030 *$} & \multicolumn{4}{|c|}{$<0.001 *$} & \multicolumn{4}{|c|}{$<0.001 *$} \\
\hline
\end{tabular}

distribution $(\mathbf{n}=130)$ : 
Table (4): Comparison between two methods (without and with tactile stimulation)

regarding physiological, behavioral\& motor and total stress score during invasive procedure in percentage distribution $(\mathrm{n}=130)$ :

\begin{tabular}{|c|c|c|c|c|c|c|c|c|c|c|c|c|}
\hline \multirow{3}{*}{$\begin{array}{l}\text { Degree of } \\
\text { stress }\end{array}$} & \multicolumn{4}{|c|}{ Physiological score } & \multicolumn{4}{|c|}{ Behavioral score } & \multicolumn{4}{|c|}{ Total stress score } \\
\hline & \multicolumn{2}{|c|}{$\begin{array}{l}\text { With tactile } \\
\text { stimulation }\end{array}$} & \multicolumn{2}{|c|}{$\begin{array}{l}\text { without tactile } \\
\text { stimulation }\end{array}$} & \multicolumn{2}{|c|}{$\begin{array}{l}\text { with tactile } \\
\text { stimulation }\end{array}$} & \multicolumn{2}{|c|}{$\begin{array}{l}\text { without tactile } \\
\text { stimulation }\end{array}$} & \multicolumn{2}{|c|}{$\begin{array}{l}\text { with tactile } \\
\text { stimulation }\end{array}$} & \multicolumn{2}{|c|}{$\begin{array}{l}\text { without tactile } \\
\text { stimulation }\end{array}$} \\
\hline & no & $\%$ & no & $\%$ & no & $\%$ & No & $\%$ & no & $\%$ & No & $\%$ \\
\hline $\begin{array}{l}\text { Adequate } \\
\text { stress } \\
\text { Control }\end{array}$ & 102 & 78.4 & 70 & 53.8 & 115 & 88.4 & 64 & 35.3 & 104 & 80 & 23 & 17.6 \\
\hline $\begin{array}{l}\text { In } \\
\text { adequate } \\
\text { stress } \\
\text { control }\end{array}$ & 28 & 21.5 & 60 & 46.1 & 15 & 11.5 & 66 & 50.7 & 26 & 20 & 107 & 82.3 \\
\hline $\mathbf{P}$ & \multicolumn{4}{|c|}{$0.000^{*}$} & \multicolumn{4}{|c|}{$0.000^{*}$} & \multicolumn{4}{|c|}{$<0.001 *$} \\
\hline$x^{2}$ & \multicolumn{4}{|c|}{17.590} & \multicolumn{4}{|c|}{46.642} & \multicolumn{4}{|c|}{100.992} \\
\hline
\end{tabular}

\section{DISCUSSION:}

Neonates entering the neonatal intensive care units (NICUs) undergo multiple painful procedures and stressful stimuli, there is clinical and scientific evidence on the adverse impact of pain and neonatal stress, and during their stay in the NICU they experience 10-18 painful and inflammatory procedures each day (Victoria \& Murphy, 2016). Neonatal pain has been shown to cause adverse effects in the short and long term, such as permanent impairment in the neuroanatomic perception of pain, behavioral, emotional changes and learning disorders (Upadhyay, 2013).

The present study was conducted on a sample of 130 neonates in NICUs. The study was carried out to test the research hypothesis that the implementation of tactile stimulation procedure could decrease neonatal stress during invasive procedures in NICUs. This goes in the same line with Cong et al, ( 2013) who illustrated that health care facilities caring for neonates should implement an effective pain prevention program which includes strategies for the following: routinely assessing pain minimizing the number of painful procedures performed effectively using pharmacological and non-pharmacological therapies for the 
prevention of pain associated with routine minor procedures and eliminating pain associated with surgery and other major procedures.

The study results lead to a positive neonates' outcome in terms of physiological, behavior and motor activities. These results regarding total stress score during invasive procedures are alarming there were high statistically significant differences between two methods (with \& without tactile stimulation) and stress control p value $<0.001$ in total stress score. Only about one fifth of neonates without tactile compared to the majority of neonates with tactile stimulation had adequate stress control. These findings are supported by Aliabadi \& Askary, (2013) who demonstrated the benefits of tactile stimulation to improve muscle tone coordination, increases circulation and sleep pattern.

Krauss et al, (2016) added that neonates have a positive response to physical contact or touch during painful procedures (venepuncture, heel lancing) as lowering of pain scores (cry duration, and heart rate vartion). In congruence with the foregoing Walker \& McGlone , (2013) added that there is a good deal of evidence that the specific quality of gentle dynamic touch received impacts on stress reliving. In the same line with Haley et al, (2013) who found that tactile stimulation benefits manual therapies such as infant massage have been proposed to modulate the stress response resulting in improved body composition and metabolism and decrease hormonal markers for stress such as cortisol and epinephrine.

Tactile stimulation is non-invasive procedure that has positive effect on physical and developmental outcomes of neonates and the responsiveness of newborns to tactile stimulation in the first days of life is greater than any other sensory modality including weight gain, promotion of neurologic and neuro-motor development, decreased stress behavior, improved infant-parent attachment, improved sleep, reduced rates of nosocomial infection and mortality rate of hospitalized premature neonates that is associated with achievement of the optimal development of their age and shorter hospital stays (Akhavan, 2013 ; Field et al, 2010 ; Wahyutami et al, 2010 ).

The findings of the present study illustrated that the neonates gestational age was around 37 weeks, and their ages around 14 days, it may be associated with the first few days 
of early life in which they still very fragile and may have immature organs in the same time they expose to painful environment, so their adaptation of these situations is very difficult. This is supported by Herrington \& Chioto, (2014) who demonstrated neonates undergo as many as one hundred painful procedures in the first two weeks of life. In the same line with Fabrizi \&Slater, ( 2012 ) who mentioned that the procedures carried out during the period of presence of neonate in NICUs may affect the neurological development of their early life.

The current study shows that respiratory distress was the most common diagnosis, it represented more than one third of sample. So the neonates need to be in oxygen therapy as a routine treatment procedure in NICUs to reduce the patient's respiratory and cardiac workload, increasing cardiac output, hemodynamic efficiency and alveolar pressure, preventing tissue hypoxia and mortality as highlighted by Arslan et al, (2017) in agreement with the present study which showed that the majority of neonates received oxygen therapy. Moreover, neonatal stress decrease production of surfactant that predisposes to increase incidence of respiratory distress syndrome (Abd El- Motalib, 2008) which makes overload on lungs and increased respiratory rate, as the present study findings pointed to during invasive procedure the majority of neonates with tactile stimulation had tachypnea then after invasive procedure the majority of them returned normal .

The findings of the current study shows that the most of the neonates were exposed to pain due to insertion of needle several times and the majority of them had the insertion duration lasted more than $5 \mathrm{~min}$.Moreover, $24.6 \%$ of the sample had complications as thrombosis, hematoma and extravasation. This might be due to stressful early life experiences in the NICUs which are inherent to high technology lifesaving care of preterm infants such as repeated skin breaches during heel sticks and intravenous line placements, other even more painful procedures as well as stressful daily care-handling and treatment events which neonates are routinely subjected to in the NICUs (Cong et al, 2017). In the same line Slater et al, ( 2010) who reported that almost $40 \%$ of neonates undergoing heel prick for blood collection have not received any form of intervention for pain reduction . 


\section{CONCLUSION:}

In the light of the main study findings, it concluded that there was extremely highly statistically significant between neonatal stress and using tactile stimulation technique during invasive procedures in Neonatal Intensive Care Units in Port Said hospitals (p value $<0.001)$. The application of tactile stimulation provide non-invasive technique that requires no special equipment and technology with decrease in the cost of treatment which has a positive effect on the neonatal degree of stress among daily painful invasive procedures.

\section{Recommendations:}

Based on the findings of this study, the following recommendations are suggested:

- Continues implementing training program on tactile stimulation techniques as a technical skill for nurses.

- Integrate developmental supportive care courses into the nursing curriculum to increase nurses' knowledge of tactile stimulation as one of non-pharmacological methods to relieve neonatal stress.

- Providing a simplified booklet in Arabic in neonatal intensive care units containing information about stress during invasive procedure in newborns and using methods to relive it.

- Implement further studies to investigate the effect of tactile stimulation on stress in other different settings.

\section{REFERENCES:}

Abd El-motalib M , (2008) : Assessment of stress in premature neonates during blood sampling procedure; master degree in nursing science, Cairo University,2008

Akhavan K, (2013): Effect of body massage on increase of low birth weightneonates' growth parameters. Iran J Reprod Med. 2013; 11(7): 583-588, 779. 
Aliabadi F \& Askary R, (2013): Effects of Tactile-Kinesthetic Stimulation on Low Birth Weight Neonates. Iran J Pediatr. June; 23(3): 289-294.

Baruch S Krauss, Lorenzo Calligaris, Steven M Green \& Egidio Barbi , (2016):Current concepts in management of pain in children in the emergency department volume 387, Issue 10013, 2-8 January 2016, Pages 83-92

Cong X , Delaney C \& Vazquez V , (2013) :Neonatal nurses' perceptions of pain assessment and management in NICUs: A national survey. Advances in Neonatal Care. 2013;13:353-360DOI: http://dx.doi.org/10.1097/ANC.0b013e31829d62e8

Cong X, , Wu J, Dorothy V, Xu W, Hussain N ,Galvin SH, Fitzsimons M, Jacqueline M, \& Wendy A , (2017) : The impact of cumulative pain/stress on neurobehavioral development of preterm infants in the NICU / Early Human Development 108 9-1

Cruz MD , Fernandes A.M \& Oliveira C.R, (2016) : Epidemiology of painful procedures performed in neonates: a systematic review of observational studies. European Journal of Pain; 20: 4, 489-498

Dobson A J, (2002): calculating sample size Trans Menziez Foundation p.p7.75.

Fabrizi L \& Slater R, (2012) : 'Exploring the relationship of pain and development in the neonatal intensive care unit', Editorial. Pain, 153: 13401. -

Fatma Taş Arslan, Sevil Özkan, Bedriye Ak,Gonca Karayağız \& MusluJ Contemp, (2017): Neonatal Intensive Care Nurses' Opinion on Oxygen Therapy: A Survey Conducted In Turkey Med 2017; 7(2):184-192.

Feldman R , Singer M \& Zagoory O, (2010): "Touch attenuates infants' physiological reactivity to stress". (2010). 13(2):271-8

Field T, Diego M , Hernandez-Reif M, (2010): Preterm infant massage therapy research:A review.Infant Behav. Dev.2010,33, 115-124. [CrossRef] [PubMed 
Grunau RE, (2013): Neonatal pain-related stress predicts cortical thickness at age7 years in children born very preterm. PLoS One 8:e7670

Grunau RE, (2013): Neonatal pain in very preterm infants: long-term effects on brain, neurodevelopment and pain reactivity. Rambam Maimonides Med J. 2013; 4 (4): e0025

Haley S, Neff K, Gulliver K, Gough G, Slater H, Lane RH \& Moyer-Mileur LJ, ( 2013) : Mechanical-tactile stimulation(MTS) intervention in a neonatal stress model alters adultadipose tissue deposition and prevents hyperinsulinemiain male rats.

Herrington C J \& Chiodo L M, (2014): Human Touch Effectively and Safely Reduces nPain in the Newborn Intensive Care Unit. Pain Management Nursing, 15(1), 107-115. doi:10.1016/j.pmn.2012.06.007. -

Radwan R I, (2014): Effect of Tactile Kinesthetic Stimulation on Growth and Neonatal behavior of Preterm.

Kulkarni A, Shankar K , Gupta P , Sharma H \& Agrawal R, (2010): Massage and touch therapy in neonates to be performed per day. Indian Pediatrics September; 17(47): 771776.

Lemus-Varela Mde L, Sola A, Golombek S, Baquero H, Borbonet D, Dávila-Aliaga C, Del Moral T\& Lara-Flores G, (2014): Consensus on the diagnostic and therapeutic approach to pain and stress in the newborn,November 1, 2014; 36 (5); 348-54..

Modrcin-McCarthy MA, McCue S \& Walker J, (1997): Preterm infants and stress: A tool for the neonatal nurse. Journal of Perinatal \& Neonatal Nursing, 10(4), 62-71

Moselhi E , (2010): The Impact of Oral Glucose on Pain Response among Preterm Baby in Neonatal Intensive Care Units Thesis submitted to the Faculty of Nursing for partial fulfillment of Doctorate degree in nursing science, Cairo university.

Nicole C Victoria \& Anne Z Murphy , (2016): The Long-term Impact of Early Life Pain On Adult Responses to Anxiety and Stress: Historical Perspectives and Empirical Evidence Exp Neurol.Exp Neurol. 2016 January; 275(Pt 2): 261-273 
Ranger M, Chau CM, Garg A, Woodward TS, Beg MF, Bjornson B, Poskitt K, Fitzpatrick K, Synnes AR, Miller SP \& Grunau RE, (2013): Neonatal pain-related stress predicts cortical thickness at age7 years in children born very preterm. PLoS One 8:e7670

Slater R , Laura Cornelissen \& Lorenzo Fabrizi, (2010): Oral sucrose as an analgesic drug for procedural pain in newborn infants: a randomised controlled trial. Lancet; 376: 9748, 1225-1232.

Slater L, Asmerom Y \& Boskovic DS, (2012): Procedural pain and oxidative stress inpremature neonates. J Pain;13:590-7

Upadhyay A, (2013): Pain in neonates. Indian J Pediatr. 2013; 80: 446-7.

Wahyutami T, Soedjatmik O, Firmansyah A \& SuradiR, (2010): Effects of massage on behavior of full-term newborns. Pediatric Indonesiana July; 50(4): 187-192-

Walker S C \& McGlone F P, (2013): The social brain: neurobiological basis of affiliative be-haviours and psychological well-being. Neuropeptides47:379393.http://dx.doi.org/10.1016/j.npep.2013.10.008. 


\title{
تأثير التحفيز باللمس على التوتز العصبي للأطفال حديثي الولادة أثناء الإجراءات الاختراقية في وحدات الرعاية المركزة لحديثي الولادة بيورسعيد
}

\author{
أ.د أمل أحمد خليل / د. عزة محمد فتحي/ أمانى على عبد الحليم.

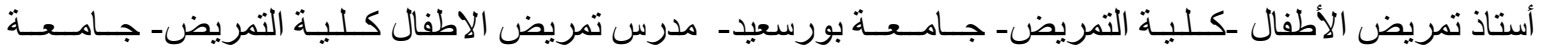 \\ بورسعيد- بكالوريوس تمريض- كـلـيـة التمريض- جـامــــة المنصورة
}

\section{الخـلاصـة}

يؤثر التحفيز عن طريق اللمس تأثثر ا كبير ا على انخفاض حدة التوتر العصبي لدي الأطفال حديثي الولادة أثناء الإجراءات الاختر اقية في وحدات الرعاية المركزة لحديثي الولادة. وتهدف الدراسة الحالية إلى تقييم تأثثر التحفيز عن طريق اللمس على التوتر العصبي للأطفال حديثي الولادة أثناء الإجراءات الاختراقية في وحدات الرعاية المركزة لحديثي الولادة بيورسعيد. تم إجراء البحث على130من حديثي الولادة. وتم أخذ العينة من وحدات الرعاية المركزة لحديثي الولادة في مستشفيات بورسعيد العام والنصر وبور فؤاد العام بمدينة بورسعيد عن طريق استخدام تصميم شبه تجريبي. وتم جمع البيانات من خلال ثلاث إستمارات: الأولي لبيانات خصائص حديثي الولادة والثانية لتقييم عينة الام لحديثي الولادة (الإجراءات الاختر اقية) و الثالثة للقياسات الفسيولوجية و السلوكية والحركية. وأظهرت النتائج أن هناك فروق إحصائية فسيولوجية وسلوكية وحركية هامه بين استخدام الطريقتين (التحفيز عن طريق اللمس وعدم استخدامه) ودرجة التحكم فى التوتر العصبي لحديثي الولادة أثناء الإجر اءات الاختراقية في وحدات الرعاية المركزة. علاوة علي ذلك , هنالك فروق إحصائية هامة بين استخدام الطريقتين (التحفيز عن طريق اللمس وعدم استخدامه) بخصوص المقياس الكلي للتوتر العصبى لحديثي الو لادة ودرجة التحكم فيه أثناء الإجر اءات الإختر اقية في وحدات الرعاية المركزة .لذا فان تطبيق التحفيز عن طريق اللمس لله تأثثر إيجابي علي تقليل درجة التوتر العصبي لحديثى الولادة وسط الاجراءات الاختراقية اليومية المؤلمة في وحدات الرعاية المركزة .ولذلك توصى الدر اسة باستمر ار تطبيق برنامج تدريبى على المهار ات الفنية للتحفيز عن طريق اللمس لأفر اد هيئة التمريض ـ وتطبيق در اسات أخري عن التحفيز عن طريق اللمس في أماكن مختلفة.

الكلمات المرشدة: التحفيز عن طريق اللمس، حديثي الولادة، التوتر العصبي، الإجراءات الاختر اقية،وحدات الرعاية المركزة 